\title{
Bioactive Compounds and Milk Peptides for Human Health-A Review
}

\author{
K Jayathilakan*, Rajkumar Ahirwar and MC Pandey \\ Freeze Drying and Animal Products Technology Division, Defence Food Research Laboratory, India
}

*Corresponding author: K Jayathilakan, Freeze Drying and Animal Product Technology Division, Defence Food Research Laboratory, Siddarthanagar, Mysore -570011, India

Submission: March, 26, 2018; Published: May 08, 2018

\begin{abstract}
Milk is a complex mixture and highly nutritious food for human being. It is an emulsion of fat globules in an aqueous environment. The aqueous portion of milk contains a variety of substances including lactose (milk sugar), protein (casein and whey), minerals and certain vitamins. It is a good source of bio peptides and other bioactive components which are necessary for body maintenance and to fight against several disease conditions. It is a good source of nutrients for any neonate of mammalian species and nourishment of adult humans. Recent studies have shown that milk furnishes a broad range of biologically active compounds that guard neonates and adults against pathogens and illnesses such as immunoglobulin, antibacterial peptides, antimicrobial proteins, oligosaccharides and lipids. Bioactive compounds are distinguished from essential nutrients which can have an influence on health. These are extra nutritional constituents that typically occur in small quantities in foods. Phenolic compounds, including their sub category, flavonoids are present in all plants and have been studied extensively in cereals, legumes, nuts, olive oil, vegetables, fruits, tea and red wine. Many phenolic compounds have antioxidant properties and some studies have demonstrated favourable effects on thrombosis and tumorigenesis. Conjugated linoleic acid, pre biotic, probiotic, bio peptides and bioactive components along with amino acids and proteins molecules are present in milk. These bioactive and peptides have lot of tertiary functions in the biological system. Application of these bio peptides and formulation of functional food products for human health is gaining lot of importance. Information pertaining to these aspects and the research and development work carried out are highlighted in this article.
\end{abstract}

Keywords: Bioactive compounds; Milk peptides; Bio-peptides; Human health

\section{Introduction}

Plant derived compounds and milk peptides are regarded as a substantial source for novel lead structures to develop medicines and biocides natural products for human health [1]. Bioactive compounds are the natural molecules synthesised by plants and animals like-alkaloids and flavonoids. The bioflavonoid are collections of low molecular weight phenolic groups of photochemical that include the anthocyanins (e.g. cyanidin, pelargonidin, petunidin), the flavonols (quercetin, kaempferol), flavones (luteolin, apigenin), flavanones (myricetin, naringin, hesperetin, naringenin), flavan-3-ols (catechin, epicatechin, gallocatechin) and although sometimes classified separately is flavones (genistein, daidzein) [2]. The anthocyanins are the most important and widespread group of colouring matters in plants. Anthocyanins are basically composed of the aromatic rings of the cyanidin from which several derivatives are generated by divergent insertions and positioning of substituent such as hydroxyl, methyl or glycosyl groups [3]. Terpenoids are derived from five carbon isoprene units that are assembled in numerous combinations to generate vast arrays of terpene derivatives collectively referred to as isoprenoids. Most terpenoids are present in the glycosides form rather than the non-polar or low polarity terpene aglycone form [4]. The coumarins natural compounds found in diverse plant sources in the form of benzopyrene derivatives. These compounds have medicinal properties and can be used as fragrance and aroma present in essential oils and industrially processed food products [5]. The coumarins are antimicrobial, anti-inflammatory, antioxidant [6,7], anti-diabetic, hepato-protective anti-thrombotic [8], anti-fungal, anti-viral [9], analgesic [10] and anti-carcinogenic agents [11]. All phenolic compounds are generally synthesized through the shikimate pathway (Figure 1) as-cinnamic acid, O-coumaric acid, P-coumaric acid, caffeic acid and ferulic acid and anthocyanins also. These are having a $\mathrm{C}_{6} \mathrm{C}_{3}$ carbon skeleton $[12,13]$.

Milk and colostrum of bovine and other dairy species are good sources of natural bioactive components. These diversified composition and functionality of milk can be found in even protein components alone. Proteins constitute serum and glandular derived compounds which are different in molecular size, concentration and functionality [14]. Milk has been more than a source of nutrients to any neonate of mammalian species, as well as for growth of children and nourishment of adult humans [15]. Bioactivity of milk components have been categorized as four major areas: 


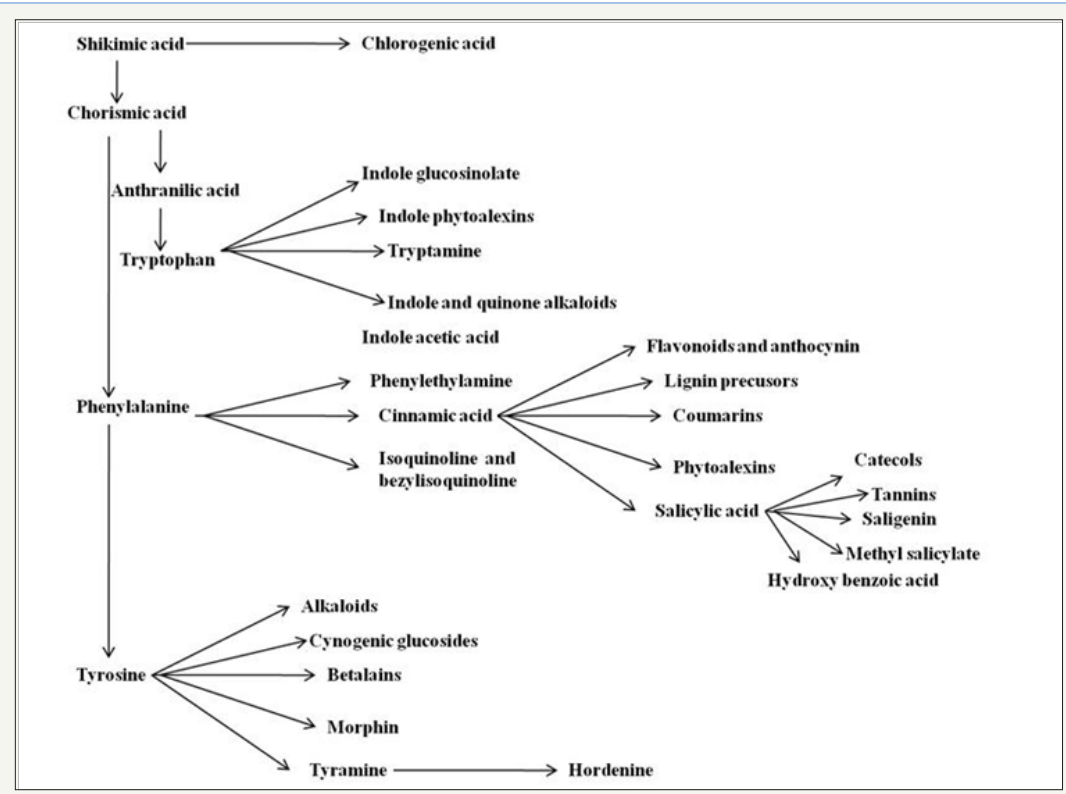

Figure 1: Shikimic acid pathway.

Adapted from Paul [12]; Ramawat [13].

a) Gastrointestinal development, activity and function

b) Immunological development and function

c) Infant development

d) Microbial activity including antibiotic and probiotic action [16].

\section{Peptides}

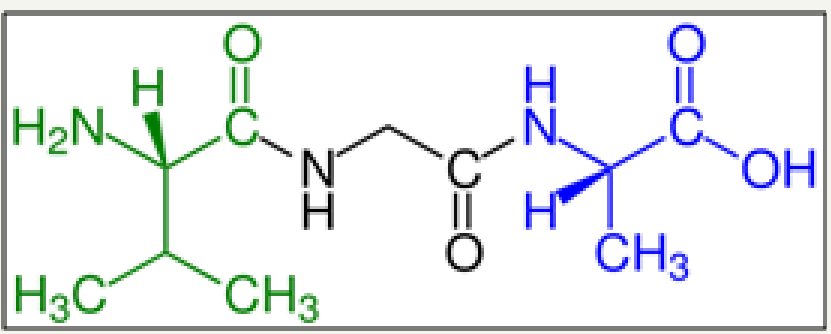

Figure 2: A tripeptide (example Val-Gly-Ala) with green marked amino end (L-Valine) and blue marked carboxyl end (L-Alanine).

Peptides are natural biological or artificially manufactured short chains of amino acid monomers linked by peptide (amide) bonds. The covalent chemical bonds are formed when the carboxyl group of one amino acid reacts with the amino group of another. The shortest peptides are dipeptides, consisting of 2 amino acids joined by a single peptide bond, followed by tripeptides, tetra peptides, etc. A polypeptide is a long, continuous and unbranched peptide chain. Hence, peptides fall under the broad chemical classes of biological oligomers and polymers, alongside nucleic acids, oligosaccharides and polysaccharides (Figure 2) [17].

\section{Milk peptides}

These are formed from milk proteins by enzymatic breakdown by digestive enzymes or by the proteinase formed by lactobacilli during the fermentation of milk. Several milk peptides have been shown to have antihypertensive effects in animal and in clinical studies. The most studied mechanism underlying the antihypertensive effects of milk peptides is inhibition of angiotensin-converting enzyme. Milk peptides may also have other additional mechanisms to lower blood pressure such as opioid-like activities and mineral-binding and antithrombotic properties. The future challenge is to identify the antihypertensive components in milk and their mechanisms of action and thus to find more possibilities for using these constituents and products as a dietary treatment of hypertension [18].

\section{Nutritive value}

Milk bio peptides provide the primary source of nutrition for young mammals before they are able to digest other types of food. Minerals present in milk are good source of bone health and body cells functioning. Various vitamins such as vitamin A, D, B12 and others are a vital source for the body coat and physiological functions. Milk produced by grass fed cows contains a beneficial fatty acid called Conjugated Linoleic Acid (CLA) [19].

Potassium, magnesium and calcium which are responsible for maintaining the strength and density of bones are present in milk. It also provides aids for protection against colon cancer, breast cancer and headaches.

\section{Generation of bioactive peptides from milk}

There are various ways for releasing bioactive peptides. First, milk proteins may be digested in vitro during food processing by maturation with selected enzymes. In this case, where milk is fermented with a proteolytic culture, the process is carefully controlled (enzyme specificity, temperature, incubation time etc.) and thus the release of bioactive peptides may be predicted [20]. Common enzymes in the commercial production of bioactive peptides via in vitro digestion include pepsin, trypsin, and 
chymotrypsin [21]. Bioactive peptides may also be generated following ingestion in vivo by either digestive enzymes or by microbial enzymes [22]. A wide range of enzymes with different cleavage sites may act throughout the whole gastrointestinal tract and under conditions which may differ depending on various physiological factors [23]. Peptides may be deliberated from their parent protein by enzymatic hydrolysis during gastrointestinal digestion, fermentation of milk with proteolytic starter cultures or hydrolysis by enzymes obtained from microorganisms [24].

\section{Gastrointestinal digestion}

Milk proteins during gastrointestinal digestion produce physiologically active peptides [25]. Hydrolysis may occur in various stages after ingestion of the protein. Hydrolysis is facilitated by proteinase such as pepsin, trypsin and chymotrypsin to produce peptides of various lengths. Some proteins may be resistant to proteinase and remain intact. Peptides may express a variety of functions either at the gastrointestinal tract, at the intestinal epithelium or after systemic absorption into circulation [26]. As concerns live microorganisms, proteolytic enzymes of lactic acid Table 1: Milk derived bioactive peptides. bacteria may be isolated, purificated and used to produce bioactive peptides from casein of different species [27].

\section{Functionalities of bioactive peptides in milk}

Bioactive components of milk are lipids, minerals, enzymes, vitamins, lactoferrin, lactose and oligosaccharides, immunoglobulin's, growth factor and cytokines, casein \& whey proteins and derived peptides. Bioactive peptides (BPs) are the most studied components in this regard. BPs have been defined as specific protein fragments that have a positive influence on physiological and metabolic functions or condition of the body and may have ultimate beneficial effects on human health. BPs can be delivered to the consumers in conventional foods, dietary supplements, functional foods, or medical foods. These bioactive peptides possess very important biological activities and functionalities, including antimicrobial, antihypertensive, anti oxidative, anti cytotoxic, immunomodulatory, opioid and mineralcarrying activities $[28,29]$. Biologically active milk components and their functions are given in (Table 1-3); [30-33].

\begin{tabular}{|c|c|c|}
\hline S no. & Body System & Functional Roll \\
\hline \multirow{3}{*}{1} & \multirow{3}{*}{ Digestive system } & Anti microbial peptides \\
\hline & & Immunomudolatory \\
\hline & & Peptides Opioid \\
\hline \multirow{4}{*}{2} & \multirow{4}{*}{ Cardiovascular system } & ACE inhibitory peptide \\
\hline & & Antithrombotic \\
\hline & & Anti -cholesterolemic \\
\hline & & Anti-hypersensitive \\
\hline \multirow{2}{*}{3} & \multirow{2}{*}{ Immune defense } & Immunomodulatory \\
\hline & & Cytomudolatory \\
\hline 4 & Nervous system & Opioid peptides \\
\hline \multirow{2}{*}{5} & \multirow{2}{*}{ Bone health } & Ca binding peptides \\
\hline & & lactoferrin \\
\hline \multirow{2}{*}{6} & \multirow{2}{*}{ Weight management } & Satiety inducing Glycomarcopeptides \\
\hline & & Opioid \\
\hline
\end{tabular}

Adapted from Mohanty [29]

Table 2: Major biologically active milk components and their functions.

\begin{tabular}{|c|c|c|}
\hline $\begin{array}{c}\text { Milk Precursors or } \\
\text { Components }\end{array}$ & Bioactive Compounds & Bioactivities Observed \\
\hline$\alpha-, \beta$-caseins & Casomorphins & Opioid agonist (Decrease gut mobility, gastric emptying rate; increase amino acids and \\
electrolytes uptake)
\end{tabular}




\begin{tabular}{|c|c|c|}
\hline$\kappa$-casein & Casoplatelins & Antithrombotic \\
\hline$\kappa$-casein & ê-caseinglyco- & Probiotic (Growth of Bifidobacteria in GI tract) macropeptide \\
\hline$\alpha$-lactalbumin ( $\alpha$-La) & Lactorphins & Opioid agonist \\
\hline \multicolumn{3}{|l|}{$\beta$-lactoglobulin ( $\beta$-La) } \\
\hline Serum albumin & Serorphin & Opioid agonist \\
\hline $\begin{array}{l}\alpha \text {-La, } \beta \text {-La and Serum } \\
\text { albumin }\end{array}$ & Lactokinins & ACE inhibitory \\
\hline Immunoglobulins & IgG, IgA & Immunomodulatory (Passive immunity) \\
\hline Lactoferrin & Lactoferrin & $\begin{array}{l}\text { Immunomodulatory (Increase natural killer cell activity, humoral immune response, thymocyte } \\
\text { trafficking immunological development, and interleukins-6; decrease tumor necrosis factor- } \alpha \text { ) } \\
\text { Antimicrobial (Increase bacteriostatic inhibition of Fe-dependent bacteria; decrease viral } \\
\text { attachment to and infections of cells) Probiotic activity (Increase growth of Bifidobacteria in GI } \\
\text { tract) }\end{array}$ \\
\hline Lactoferrin & Lactoferroxins & Opioid antagonist \\
\hline Oligosaccharides & Oligosaccharides & Probiotic (Increase growth of Bifidobacteria in GI tract) \\
\hline Glycolipids & Glycolipids & \multirow{2}{*}{ Antimicrobial (Decrease bacterial \& viral attachment to intestinal epithelial cells) } \\
\hline Oligosaccharides & Oligosaccharides & \\
\hline Prolactin & Prolactin & $\begin{array}{c}\text { Immunomodulatory (Increase lymphocyte and thymocyte trafficking, and immune } \\
\text { development) }\end{array}$ \\
\hline \multirow{5}{*}{ Cytokines } & Interleukins-1,2,6, \& 10 & \multirow{5}{*}{ Immunomodulatory (Lymphocyte trafficking, immune development) } \\
\hline & Tumor necrosis factor- $\alpha$ & \\
\hline & Interferon- $\gamma$ & \\
\hline & $\begin{array}{c}\text { Transforming growth } \\
\text { Factors- } \alpha, \beta \text {; leukotriene } \\
\text { B4 }\end{array}$ & \\
\hline & Prostagland in E2, Fn & \\
\hline Growth factors & IGF- 1 , TGF- $\alpha$, EGF, TGF- $\beta$ & Organ development and functions \\
\hline Parathromone-P & PTHrP & Increase $\mathrm{Ca}+2$ metabolism and uptake \\
\hline
\end{tabular}

Adapted from Schanbacher [30] Clare \& Swaisgood [31] and Park [32]

Table 3: Bioactive peptides derived from whey proteins.

\begin{tabular}{|c|c|c|c|c|}
\hline Precursors Protein & Fragment & Peptide Sequence & Name & Function \\
\hline$\alpha$ - lactalbumin & $50-53$ & Tyr-Gly-Leu-Phe & $\alpha$-Lactorphin & Opioid agonist ACE inhibition \\
\hline$\alpha$-lactoglobulin & $102-105$ & Tyr-Leu-Leu-Phe & $\begin{array}{c}\text { Non-opioid stimulatory effect on } \\
\text { ileum }\end{array}$ \\
\hline & $142-148$ & Ala-Leu-Pro-Met-His-Ile-Arg & $\beta$-Lactotensin & ACE inhibition \\
\hline Bovine serum albumin & $146-149$ & His-Ile-Arg-Leu & Serorphin & Opioid \\
\hline & $208-216$ & $\begin{array}{c}\text { Ala-Leu-Lys-Ala-Trp-Tyr-Gly-Phe-Gln-Asp- } \\
\text { Ala }\end{array}$ & Albutensin A & Ileum contraction, ACE inhibition \\
\hline Lactoferrin & $17-42$ & $\begin{array}{c}\text { Lys-Cys-Arg-Arg-Trp-Glu-Trp-Arg-Met-Lys- } \\
\text { Lys-Leu-Gly-Ala-Pro-Ser-Ile-Thr-Cys-Val- } \\
\text { Arg-Arg-Ala-Phe }\end{array}$ & Lactoferricin & Antimicrobial \\
\hline
\end{tabular}

Adapted from Korhonen [33]

\section{Antihypertensive peptides}

$30 \%$ of the adult population in most countries are affected by hypertension which is a known risk factor for cardiovascular diseases, including coronary heart disease [34]. Because of high prevalence and severe consequences, hypertension poses an important, world-wide health challenge. Peptides may be deliberated from their parent protein by enzymatic hydrolysis during gastrointestinal digestion, fermentation of milk with proteolytic starter cultures or hydrolysis by enzymes obtained from microorganisms [35].

Angiotensin is a peptide hormone that causes vasoconstriction and a subsequent increase in blood pressure. It is part of the rennin-angiotensin system, which is a major target for drugs that raises blood pressure. Angiotensin also stimulates the release of aldosterone, another hormone, from the adrenal cortex. Aldosterone promotes sodium retention in the distal nephron, in the kidney, which also drives blood pressure up [36]. 
Angiotensin converting enzyme (ACE) inhibitor peptides have shown the ability to lower blood pressure by limiting the vasoconstrictory effects of Angiotensin and potentiating the vasodilator effects (ref). The ACE-inhibitory peptides derived from proteins and products of goat milk have received much attention. The structure-activity of ACE-inhibitory peptides is strongly increased by the presence of hydrophobic (aromatic or branched chains) tripeptidic C-terminal sequence of the peptides. Several factors were reported to be responsible for the type and concentration of ACE-inhibitory peptides in different cheeses including goat cheeses [37].

\section{Antioxidative peptides}

Antioxidant activity of bioactive peptides can be attributed to their radical scavenging, inhibition of lipid peroxidation and metal ion chelation properties of peptides. It also has been proposed that peptide structure and its amino acid sequence can affect its anti oxidative properties [38]. Peptides derived from $\alpha$ s-casein have free radical-scavenging activity and inhibit enzymatic and nonenzymatic lipid peroxidation [39]. These dipeptides can promote the synthesis of glutathione, which is an important antioxidant for cellular protection and repair processes.

\section{Opioid peptides}

Opioid peptides function both as hormones and neurotransmitters and are synthesized in vivo. Classifications of these peptides are carried out depending on their bioactivity as opioid agonists or antagonists. $\beta$-casomorphins derived from $\beta$-casein and particularly $\beta$-casomorphin-5 (BCM5) and $\beta$-casomorphin-7 (BCM7), are the best-known opioid peptides [40]. These are peptides that bind to opioid receptors in the brain; opiates and opioids mimic the effect of these peptides. Opioid-like peptides may also be absorbed from partially digested food (casomorphins, exorphins and rubiscolins). The opioid food peptides have lengths of typically 4-8 amino acids. These are released by post-translational proteolytic cleavage of precursor proteins [41].

\section{Antimicrobial peptides}

Anti microbial peptides, also called host defense peptides are part of the innate immune response found among all classes of life. Fundamental differences exist between prokaryotic and eukaryotic cells that may represent targets for antimicrobial peptides. These peptides are potent, broad spectrum antibiotics which demonstrate potential as novel therapeutic agents [42]. The total antibacterial effect in milk is greater than the sum of individual immunoglobulin and non immunoglobulin such as lactoferrin, lactoferricins, lactoperoxidase, lysozyme, lactenin and casecudubs [43].

\section{Antithrombotic peptides}

These peptides reduce or inhibit the formation of blood clots. Caseinomacropeptide is a peptide split from k-casein when the milk protein is coagulated by rennin enzyme. This has functions of inhibiting the aggregation of blood platelets and binding of the human fibrinogen $\gamma$-chain to platelet surface fibrinogen receptors
[44]. There are two reported antithrombotic peptides, derived from human and bovine k-caseino glycopeptides [45].

\section{Cytomodulatory peptides}

Caseinophosphopeptides have also been reported to exhibit cytomodulatory effects. These peptides obtained from casein fractions can inhibit cancer cell growth or stimulate the activity of immune competent cells and neonatal intestinal cells. Caseins derived peptides can modulate cell viability such as proliferation and apoptosis in different human cell cultures. These peptides can also inhibit cancer cell growth or stimulate the activity of immunocompetent cells and neonatal intestinal cells [46]. Peptides derived from milk act as specific signals that may trigger viability of cancer cells [47].

\section{Antiappetizing peptides}

By suppressing the appetite these peptides can function by preventing the weight gain and obesity. The total whey protein in the diet has been associated with a lowering of LDL cholesterol and also related to the increased release of an appetite suppressing hormone, cholecystokinin [48]. Combinations of active whey protein fractions or amino acid sequences are responsible for the bioactive functions of total whey protein.

\section{Lactoferrin}

This is a dominant whey protein in human milk and plays an important role in iron uptake in the intestine. Bovine lactoferrin and human lactoferrin are homologous. The concentration of lactoferrin in bovine colostrum and milk is about $1.5-5 \mathrm{mg} / \mathrm{ml}$ and $0.1 \mathrm{mg} / \mathrm{l}$, respectively. Milk of other mammalian species such as cow, pig, horse, buffalo, goat and mouse has also been identified with lactoferrin presence in different concentrations. On a commercial basis, lactoferrin is isolated from cow's milk. This can also be found in tears, synovial fluids, saliva and seminal fluid, with concentrations ranging from $10 \mu \mathrm{g} / \mathrm{ml}$ to about $2 \mathrm{mg} / \mathrm{ml}$ [49]. The importance of lactoferrin for humans than for bovine species is clearly indicated.

\section{Summary and Conclusion}

This review concentrates on critical evaluation of the present published data on various milk derived peptides. The health promoting, functional and performance enhancing ability of bioactive peptides have been established by various researchers which include anti hypertensive, cytomodulatory, antiappetizing, antithrombotic, opioid, anti microbial and lactoferrin. Even then there are some grey areas which can be addressed through the application of advanced technologies, enriched products and molecular approaches. Novel techniques have to be focused including advanced proteomics approaches, recombinant enzyme technologies and microbial fermentation. The impact of bioactive peptides on expression of genes and also to optimize the nutritional and health effects can be established by employing these techniques. Allergen city, toxicity and stability of these bioactive peptides during gastrointestinal digestion have to be established which will 
give an insight in to the designing and formulation of the functional food products. Separation and identification of milk derived bioactive peptides and their pharmaco-dynamic parameters have to be evaluated carefully before transferring their potent functional properties into food and clinical applications. The production of bioactive peptides during milk fermentation using genetically modified organisms could be an area of interest for future research. Moreover, peptides with modified sequences can be designed in a view to increase their stability, functionality and duration of action.

More emphasis on legal regulatory measures with regard to the health claims attached to the products have to be implemented as the interest on developing foods possessing health promoting or disease preventing properties has been increasing. Authorities around the world have had to develop systematic approaches for review and assessment of scientific data.

\section{References}

1. Yazdani D, Tan YH, Zainal Abidin MA, Jaganath IB (2011) A review on bioactive compounds isolated from plants against plant pathogenic fungi. Journal of Medicinal Plants Research 5(30): 6584-6589.

2. Lila MA (2004) Anthocyanins and human health: An in vitro investigative approach. J Biomed Biotechnol 2004(5): 306-313.

3. Lazze MC, Pizzala R, Savio M, Stivala LA, Prosperi E, et al. (2003) Anthocyanins protect against DNA damage induced by tert-butylhydroperoxide in rat smooth muscle and hepatoma cells. Mutat Res 535(1): 103-115.

4. Attard E, Pacioni P (212) The phytochemical and in vitro pharmacological testing of maltese medicinal plants. In: Rasooli I, (Ed.), Bioactive Compounds in Phytomedicine. In Tech Publisher, USA, pp. 93-112.

5. Karayil S, Chandran KPS, Sudeesh, PS, Veraiah K (2014) Isolation and structural elucidation of novel bioactive molecule-Coumarin from traditionally used medicinal plant-Ceropegia juncea (Roxb.). IOSR Journal of Pharmcology Biological Science 9(3): 19-22.

6. Sardari S, Nishibe S, Daneshtalab M (2000) Coumarins, the bioactive structures with antifungal property. Studies in Natural Products Chemistry 23: 335-393.

7. Prabakaran D, Ashok Kumar N (2013) Protective effect of esculetin on hyperglycemia-mediated oxidative damage in the hepatic and renal tissues of experimental diabetic rats. Biochimie 95(2): 366-373

8. Jain DP, Pancholi SS, Patel R (2011) Synergistic antioxidant activity of green tea with some herbs. J Adv Pharm Technol Res 2(3): 177-183.

9. Patel RM, Patel NJ (2011) In vitro antioxidant activity of coumarin compounds by DPPH, super oxide and nitric oxide free radical scavenging methods. Journal of Advanced Pharmacy Education \& Research 1: 52-68,

10. Khan IA, Kulkarni MV, Gopal M, Shahabuddin MS, Sun CM (2005) Synthesis and biological evaluation of novel angularly fused polycyclic coumarins. Bioorg Med Chem Lett 15(15): 3584-3587.

11. Matos MJ, Mura F, Vazquez Rodriguez S, Borges F, Santana L, et al. (2015) Study of coumarin-resveratrol hybrids as potent antioxidant compounds. Molecules 20(2): 3290-3308.

12. Paul C, Chikezie, Chiedozie O, Ibegbulem, Ferdinand (2015) Bioactive Principles from Medicinal Plants. Research Journal of Photochemistry 9: 88-115.

13. Ramawat K, Dass S, Mathur M (2009) The Chemical Diversity of Bioactive Molecules and Therapeutic Potential of Medicinal Plants. In: Ramawat K, (Ed.), Herbal Drugs: Ethnomedicine to Modern
Medicine. Springer, Berlin, Heidelberg, Germany, pp. 7-32,

14. Regester GO, Smithers GW, Mitchell IR, McIntosh GH, Dionysius DA (1997) Bioactive factors in milk: Natural and induced In: Welch R, Burns D, Davis S, Popay A, Prosser C, (Eds.), Milk composition, production and biotechnology. CAB International, UK, pp. 119-132.

15. Park YW (2009) Bioactive components of goat milk. In: Park YW, (Ed.), Bioactive components in milk and dairy products. Wiley Blackwell Publishers, Ames, Iowa and Oxford, England, pp. 43-82.

16. Gobbetti M, Minervini F, Rizzello CG (2007) Bioactive peptides in dairy products. In: Hui YH, (Ed.), Handbook of food products manufacturing. John Wiley \& Sons, New Jersey, USA, pp. 489-517.

17. Lindorff K, Rogen P, Poci E, Vendruscolo M, Dobson M (2005) Protein folding and the organization of the protein topology universe. Trends in Biochem Sci 30(1): 13-19.

18. Jauhiainen T, Korpela R (2007) Milk peptides and blood pressure. J Nutr 137: 825-829.

19. Midau A, Kibon A, Moruppa SM, Augustine C (2010) Influence of season on milk yield and milk composition of red sokoto goats in mubi area of Adamawa State, Nigeria. International Journal of Dairy Science 5(4): 135-141.

20. Bianca Maria E (2001) A review of recent developments in the use of moderately hydrolyzed whey formulae in infant nutrition. Nutrition Research 21(1-2): 355-379.

21. Korhonen H, Anne PL, Rantamaki P, Tupasela T (1998) Impact of processing on bioactive proteins and peptides. Trends in Food Science \& Technology 8(9): 307-319.

22. Kekkonen N, Lafreniere M, Ebara A, Saitob Y, Sawab (2009) Synthesis and characterization of biocompatible magnetic glyconanoparticles. Journal of Magnetism and Magnetic Materials 321(10): 1393-1396.

23. Toni M Antalis, Terez Shea Donohue, Stefanie N Vogel, Cynthia Sears, Alessio Fasano (2007) Mechanisms of Disease: protease functions in intestinal mucosal pathobiology. Nat Clin Pract Gastroenterol Hepatol 4(7): 393-402.

24. Phelan M, Aisling A, Fitz Gerald RJ, O’Brien NM (2009) Casein-derived bioactive peptides: Biological effects, industrial uses, safety aspects and regulatory status. International Dairy Journal 19(11): 643-654.

25. Hernandez LB, Amigo L, Ramos M, Recio I (2004) Angiotensin converting enzyme inhibitory activity in commercial fermented products. Formation of peptides under simulated gastrointestinal digestion. J Agric Food Chem 52(6): 1504-1510.

26. Shimizu M (2004) Food derived peptides and intestinal functions. Bio Factors 21(1-4): 43-47.

27. Minervini F, Algaron F, Rizzello CG, Fox PF, Monnet V, et al. (2003) Angiotensin Iconvertingenzymeinhibitory and antibacterial peptides from Lactobacillus helveticus PR4 Proteinasehydrolyzed caseins of milk from six species. Appl Environ Microbiol 69: 5297-5305.

28. Kitts DD, Weiler K (2003) Bioactive proteins and peptides from food sources. Applications of bioprocesses used in isolation and recovery. Curr Pharm Des 9(16): 1309-1323.

29. Mohanty DP, Mohapatra S, Misra S, Sahu PS (2016) Milk derived bioactive peptides and their impact on human health- A review. Saudi J Biol Sci 23(5): 577-583.

30. Schanbacher FL, Talhouk RS, Murray FA, Gherman LI, Willett LB (1998) Milk-borne bioactive peptides. International Dairy Journal 8(5-6): 393403.

31. Clare DA, Swaisgood HE (2000) Bioactive milk peptides: a prospectus. J Dairy Sci 83(6): 1187-1195. 
32. Young Woo Park, Nam MS (2015) Bioactive peptides in milk and dairy products: A Review. Korean J Food Sci Anim Resour 35(6): 831-840.

33. Hannu Korhonen, Anne PL, Pirjo R, Tuomo T (1998) Impact of processing on bioactive proteins and peptides. Trends in Food Science \& Technology 9(8-9): 307-319.

34. Kearney PM, Whelton M, Reynolds K, Muntner P, Whelton PK (2005) Global burden of hypertension: analysis of worldwide data. The Lancet 365(9455): 217-223.

35. Phelan M, Aisling A, Fitz Gerald RJ, O Brien NM (2009) Casein-derived bioactive peptides: Biological effects, industrial uses, safety aspects and regulatory status. International Dairy Journal 19(11): 643-654.

36. Park YW (2009) Bioactive components of goat milk. In: Park YW, (Ed). Bioactive Components in Milk and Dairy Products. Wiley Blackwell Publishers; Ames, Iowa and Oxford, England, pp. 43-82.

37. Ondetti MA, Cushman DW (1984) Angiotensin-converting enzyme inhibitors: biochemical properties and biological actions. CRC Critical Reviews in Biochemistry. 16: 381-411.

38. Sarmadi BH, Ismail A (2010) Anti oxidative peptides from food proteins: a review. Peptides Biochimie 31(10): 1949-1956.

39. Rival SG, Boeriu CG, Wichers HJ (2001) Caseins and casein hydrolysates. 2. Antioxidative properties and relevance to lipoxygenase inhibition. J Agric Food Chem 49(1): 295-302.

40. Schlimme E, Meisel H (1995) Bioactive peptides derived from milk proteins. Structural, physiological and analytical aspects. Nahrung 39(1): 1-20.
41. Rokka T, Syvoja EL, Tuominen J, Korhonen H (1997) Release of bioactive peptides by enzymatic proteolysis of Lactobacillus GG fermented UHT milk. Milchwissenschaft 52(12): 675-678.

42. Yamaguchi N, Kawaguchi K, Yamamoto N (2009) Study of the mechanism of antihypertensive peptide VPP and IPP in spontaneously hypertensive rats by DNA microarray analysis. Eur J Pharmacol 620(1-3): 71-77.

43. Gobbetti M, Minervini F, Rizzello CG (2007) Bioactive peptides in dairy products. In: Hui YH, (Ed). Handbook of food products manufacturing. John Wiley \& Sons, USA, pp. 489-517.

44. Fiat AM, Miglilore SD, Jolles P, Drouet L, Sollier C, et al. (1993) Biologically active peptides from milk proteins with emphasis on two example concerning antithrombotic and immunomodulating activities. J Dairy Sci 76(1): 301-310.

45. Chabance B, Marteau P, Rambaud JC, Migliore SD, Jolles P, et al. (1998) Casein peptided release and passage to the blood in humans during digestion of milk or yogurt. Biochimie 80(2): 155-165.

46. Hartmann R, Meisel H (2007) Food-derived peptides with biological activity: from research to food applications. Current Opinion in Biotechnology 18(2): 163-169.

47. Zhang X, Beynen A (1993) Lowering effect of dietary milk whey protein v. casein on plasmaand liver cholesterol concentrations in rats. Br J Nutr 70(1): 139-146.

48. Steijns JM, Van Hooijdonk AC (2000) Occurrence, structure, biochemical properties and technological characteristics of lactoferrin. Br J Nutr 84: $11-17$
Creative Commons Attribution 4.0

International License

For possible submissions Click Here

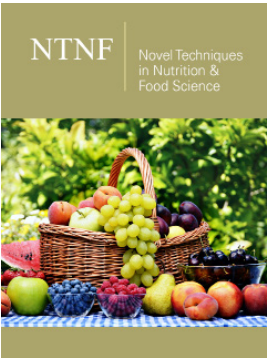

Novel Techniques in Nutrition and Food Science

\section{Benefits of Publishing with us}

- High-level peer review and editorial services

- Freely accessible online immediately upon publication

- Authors retain the copyright to their work

- Licensing it under a Creative Commons license

- Visibility through different online platforms 